Research Article

\title{
Estimation of Standby Power Consumption for Typical Appliances
}

\author{
P. Ajay -D- Vimal Raj ${ }^{1 *}$, M. Sudhakaran ${ }^{1}$ and P. Philomen-D-Anand Raj ${ }^{2}$ \\ ${ }^{1}$ Department of Electrical and Electronics Engineering, Pondicherry Engineering College, Pondicherry -605014, India. \\ ${ }^{2}$ Mothilal Nehru Government Polytechnic, Pondicherry, India.
}

Received 8 April 2009; Revised 1 May 2009; Accepted 3 November 2009

\begin{abstract}
In the past days, many consumers could simply unplug their appliances and go on holidays, assuming that their electricity meter would just stop. Standby power is a power consumed by an appliance when switched off or not performing its primary functions. Standby power consumption provides good opportunity for reducing both energy consumption and green house gas emissions. Through co-operation among governments, industry and consumers and the co-ordination of international policies, standby modes can be made more efficient, thereby reducing the overall demand for power.

In this paper, standby power consumption of various domestic appliances was determined using an energy cost meter. The experimental results shows that the standby power of various house hold electrical appliances is consuming more electricity during standby mode.
\end{abstract}

Keywords: Standby power consumption, energy cost meter, energy labeling, domestic appliances.

\section{Introduction}

Electrical Energy is the basic necessity for the economic development of any country. Many functions in our present day living will grind to a halt when the supply of energy stops. The energy used per person has a close relationship with the standard of his/ her living. The greater the per capacity consumption of energy in a country, the higher the standard of living of its people, under the provision of Electricity Act (EC Act). In [1] Mohanty et al. presented energy efficiency of office equipment in commercial buildings. Mohanty et al. discussed the perspectives for standby power consumption in electrical appliances [2]

Our country has taken several steps to mobilize the energy efficiency products in the market. Standby electricity is the energy consumed by appliances when they are not performing their main functions or when they are in standby mode. In [3] Alan Meier presented the importance of conservation of standby power for saving the energy consumed. The standby power consumption during night mode was highlighted in [4]. The energy wasted in this manner is commonly referred to as "standby loss" or "leakage electricity". The standard of living and the economic growth is purely based on how much energy produced, utilized and energy saved. Most people are not aware of the fact that modern electrical and electronic appliances, even those having on/off switches, consume power for standby functions. The number of products with standby power consumption is growing rapidly in both quantity and diversity. Several products commercialized in the market

* E-mail address: ajayvimal@yahoo.com ISSN: 1791-2377 (C) 2009 Kavala Institute of Technology. All rights reserved. today do not have any hard "off" switches. Many appliances have no standby features but are equipped with external power supplies (commonly known as wall-packs). Even when they are not performing any operation or are switched off, a small amount of energy is lost in low voltage power supplies, mainly due to the cheap transformers with high core losses. Household appliances and office equipment such as televisions (TVs), video recorders, audio players, telephone answering and facsimile machines, computers, printers and copiers contribute to this standby loss which is relatively low, with typical loss per appliance ranging from less than $1 \mathrm{~W}$ to as much as $25 \mathrm{~W}$. The economic social benefits for the promotion of sustainable energy were discussed in [5].

In developing countries, there is lower penetration of electronic products in homes and offices and one would normally expect much lower standby power consumption of households as compared with their counterparts in the industrialized world. Takaji Matsunngaa made a survey on actual house hold appliances in [6]. However, the appliances that are available in the market are often not the state -of- art products sold in developed countries. No detailed field surveys are currently available for developing countries in the Asia and Pacific region. Marker et al. discussed the standby power consumption in Australia [8].The standby energy use per household would reduce from 398 to $228 \mathrm{kWh} /$ year, representing savings of almost 43 per cent by the utilization of energy saving products. Industry has proven that savings as high as 90 per cent can be achieved in many appliances without any reduction in services and at low or no cost. 
Let us take a concrete case. One may watch the TV for 4 hours in a day. The power demand of the TV when it is working may be 70 Watts. After watching, one may use the remote to put the TV on stand by mode (TV is not working but the LED is on; there are many other electrical and electronic circuits on to ensure that when the remote is used again, the TV should start functioning as soon as possible). If one measures the power consumed by the TV on standby mode, one may find that the power demand is 8 Watts.

When one is watching the TV, the electricity consumption would be 70 Watts $* 4$ hours $=280$ Watt - hours.

When one is not watching the TV, the electricity still being consumed would be 8 Watts $* 20$ hours $=160$ Watt - hours.

As a result, one end up by using more than $50 \%$ excess electricity by keeping the TV on standby mode instead of switching it off completely.

This is becoming a non-negligible problem with many new electrical appliances that have standby facilities or are switched off at the front by not unplugging. For example, when one switches off the computer through the OS, the transformer inside the computer continues to work and if one installs the electric cost meter, one can still measure a small amount of power demand (1 or 2 Watts). Millions of these small devices add up to several hundreds of MW o f electricity and it is lost unnecessarily.

As a preliminary step one can measure the consumption of energy by various devices and save lot of energy to the nation by switching off the devices.

Various national studies have been conducted to estimate the standby power losses at homes and offices. Some of these studies are based on field measurements and others are "bottom-up" estimates. The type of appliances taken into consideration for evaluating the total standby power loss are mostly the common ones found in many countries. The different categories of appliances include:

- Audio and video equipment such TVs, VCRs, tape cassettes, compact disc (CD) players and DVD players, speakers and sound systems

- Telephony equipment such as cordless telephones, answering machines and intercoms

- Kitchen appliances such as microwave ovens, conventional electrical ovens, table top ovens, rice cookers, bread makers etc.,

- Set-top boxes such as analog and digital cable TV boxes, TV decoders, internet terminals, satellite TV systems

- Office appliances such as PCs and monitors, modems, ink jet and laser printers, scanners, photocopy machines, typewriters

- Battery operated devices that require charging such as notebook computers, laptop computers, personal digital assistant (palmtops), hand-held power tools including vacuum cleaners and shavers

- Miscellaneous home appliances such as security systems, water treatment units, door openers, timers, low-voltage halogen lamps, motion sensor.

\section{Method to reduce standby power consumption}

There are basically two methods to reduce the standby power consumption; behavioral and technical. The first one involves better consumer awareness and education of standby energy consumption. In some countries, local power utilities conduct information and motivation campaigns to raise consumer's awareness and encourage the purchase of equipment with reduced standby consumption.

This approach has its own merits and drawbacks. It is not easy to convince the end-used of the economic and environmental benefits of adopting energy efficiency practices, particularly when savings are not high at the individual level. Reaching out to each and every household in a country requires considerable human and financial resources. This may be perceived as not the most cost-effective option for public authorities. Moreover, manufacturers are incorporating programmable clocks and timers in more and more appliances that require continuous flow of electricity, even when the equipment is not in operation. PCs connected to a network are required to be in standby mode to avoid communication problem with peripheral devices or with the network manager. So it may sometimes be impractical to ask people to unplug appliances that are not in use.

The second method of reducing standby power consumption in many appliances is the adoption of technological innovations. It is estimated that redesigning appliance circuits can reduce standby power consumption up to 90 per cent.

\section{Calculation of standby power consumption for various Do- mestic Appliances}

Energy Cost Meter is used to measure the Standby power for various domestic appliances. With the energy cost meter on may used to determine how much electricity a house hold product as consumed. Energy cost meter is a device reprogrammed to measure 24 hours and it can be also be reprogrammed to measure for 7 or 30 days or a period by own's choice. Using the energy-cost checker the electricity-tariff is in advance set to 1.55 ; if the tariff in an area. It can be also changed or adjusted with the tariff of the various respective areas.

\section{Method for measurement of standby Power (W) using En- ergy-Cost-Meter}

The following steps are carried out for measuring the standby power using the meter:

1. Plug in the energy-cost-checker (One can use extension cord)

2. Put the plug of the unit in the energy-cost-checker. The Measuring(24 hours)

3 . The display now shows the actually $\mathrm{kWh}$ and the price per year (if the unit has the same kWh 24 hours a day).

4. By pressing the key the following information in the display are obtained.

i. Energy input $(\mathrm{kWh})$ in the measured time.

ii. Costs/tariff measured during on time.

iii. Smallest wattage which has been measured during on time.

iv. Highest wattage which has been measured during on time.

v. The ampere of the unit measured during on time. 
vi. The actually voltage measured.

vii. The actually $\mathrm{kWh}$ and costs per year.

5. By pressing the key "Time" the following information at the display is obtained:

a) REC TIME is the complete recording time.

b) ON TIME is the time, the consumer has been switched on.

6. After 24 hours the measuring stops. The information described under 4 and 5 can be obtained. To return to normal mode after 24 hours, press the key "START/STOP” for a few seconds.

7. The instrument is ready for new measurement.

c) The time is show in minutes/seconds, later in hours/ minutes and at last in days/hours.

d) REC TIME and ON TIME will only be different when measuring units which automatically turns on and off, for example your refrigerator or iron.

\section{A. Standby power consumption of an External modem for a computer:}

1. Energy input $(\mathrm{kWh})$ during the measured Time

$: 0.042 \mathrm{kWh}$

2. Cost/Tariff (Set the tariff at the tariff rate for 1.55) $: 0.062$

3. Smallest Wattage

$: 1.0 \mathrm{~W}$

4. Highest Wattage

$: 7.2 \mathrm{~W}$

5. The amperage of the unit measured during on Time

6 . The measured voltage measured

7. The actual kWh \& Cost per year

Assume the modem is on standby for "a" hours and was on working for "b" hours.

$$
\begin{gathered}
a+b=24 \text { (Total number of hours over which } \mathrm{kWh} \text { is recorded) } \\
1 a+7.2 b=42 \mathrm{Wh} \\
1 a+7.2(24-a)=42 \mathrm{Wh} \\
a=21 \text { hours; } b=3 \text { hours }
\end{gathered}
$$

The modem is working for 3 hours and was on standby for 21 hours. The power consumption would be

$$
(7 \text { Watts } \times 3 \text { hours })+(1 \text { Watt } \times 21 \text { hours })=42 \text { Watt-hours }
$$

During standby mode the modem is consuming 21 watt hours, the excess of electricity is consumed by keeping the external modem on standby mode instead of switching it off completely.

\section{B. Standby power consumption for a Refrigerator:}

For the case of a refrigerator, one may like to know how many hours the compressor of the refrigerator has been operating over a period of 24 hours. The compressor starts when the temperature inside the refrigerator becomes high and stops when the set temperature is reached. After 24 hours of recording, the following data's have been recorded.

Lowest demand $=10$ Watts (when the refrigerator compressor is off) Highest demand $=125$ Watts (when the refrigerator compressor is on) $k W h$ reading after 24 hours $=1.62 \mathrm{kWh}(1620 \mathrm{Wh})$

Assume that the refrigerator compressor is on for "a" hours

and off for "b" hours

$$
\begin{gathered}
a+b=24 \text { (The total number of hours over which } \mathrm{kWh} \text { is re- } \\
\text { corded) } \\
10 a+125 b=1620 / \text { Wh) } \\
\text { Substituting } b=24-a \text {, we get } \\
10 a+125(24-a)=1620 \text { or }-115 a+3000=1620 \text { or } 115 a=1380
\end{gathered}
$$

Thus $a=12$ hours and $b=12$ hours. The compressor of the refrigerator is "On" for 12 hours and is "Off" for 12 hours.

\section{Standby power consumption for a Home Television}

Time Duration

Energy Input (KWh) in the measured Time

Cost/Tariff measured during on time

Smallest wattage measured during On time

Highest wattage measured during On time

Instantaneous Current

Instantaneous Voltage

1 Day
$0.608 \mathrm{kWh}$
0.899
$2.2 \mathrm{~W}$
$83 \mathrm{~W}$
$0.383 \mathrm{~A}$
$211 \mathrm{~V}$

Let us assume the television "On" for "a" hours and "Off" for " $b$ " hours.

$$
\begin{gathered}
a+b=24 \text { hours } \\
2.2 a+83 b=608 \mathrm{Wh} \\
b=24-a \\
\text { Resolving, } a=17 \mathrm{hrs} ; b=7 \mathrm{hrs}
\end{gathered}
$$

Conclusion the TV is on for 7 hours and off for 17 hours then the consumption would be

$$
\begin{gathered}
(2.2 \text { Watts } \times 17 \text { hours })+(83 \text { Watts } \times 7 \text { hours })=618.4 \text { Wh }= \\
0.6184 \mathrm{kWh}
\end{gathered}
$$

For the above case study the during the "On" period the TV is consuming $581 \mathrm{Wh}$ and during the "Off" period it is consuming 37.4 Wh as the standby power.

\section{Energy Labeling}

Appliance labeling is a convenient tool for providing required information to the consumer for making purchase decisions and selecting efficient models. Energy-efficiency labels are affixed to manufactured products to describe their energy performances. The effectiveness of energy labels depends on how information is presented to the consumer. Most appliances sold in the market should be labeled .If consumers do not make an effort to distinguish between efficient and inefficient appliances, increased awareness and labeling may not have much effect.

Appliance labeling can provide and effective way to monitor the market and compile information on market transformation. Public authorities and power utilities can use labels as energy efficiency benchmarks to offer incentives for buying energy efficient products.

Table 1 infers the experimental results of electrical energy consumed through various devices during the standby mode for various devices for the period of 24 hours. 
Table 1. End use metering of standby power consumption of various domestic appliances

\begin{tabular}{|c|c|c|c|c|c|c|}
\hline 造 & 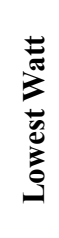 & 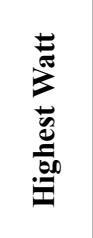 & 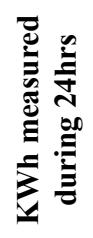 & 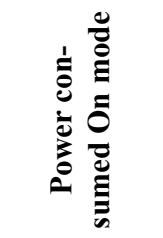 & 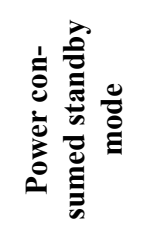 & 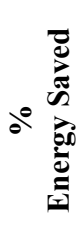 \\
\hline TV & 2.2 & 83 & 0.608 & $\begin{array}{c}581 \mathrm{~W} \text { for } 7 \\
\text { hours }\end{array}$ & $\begin{array}{c}37.4 \mathrm{~W} \text { for } \\
17 \text { hours }\end{array}$ & 15.6 \\
\hline $\begin{array}{l}\text { Refrig- } \\
\text { erator }\end{array}$ & 8.1 & 1101 & 4.051 & $\begin{array}{c}440.4 \mathrm{~W} \text { for } \\
4 \text { hours }\end{array}$ & $\begin{array}{l}162 \mathrm{~W} \text { for } \\
20 \text { hours }\end{array}$ & 18.3 \\
\hline Modem & 1.0 & 7.2 & 0.042 & $\begin{array}{c}21 \mathrm{~W} \text { for } 3 \\
\text { hours }\end{array}$ & $\begin{array}{l}\text { for } 21 \\
\text { hours }\end{array}$ & 50 \\
\hline CPU & 1.5 & 108.9 & 0.148 & $\begin{array}{c}108.9 \mathrm{~W} \text { for } \\
1 \text { hour }\end{array}$ & $\begin{array}{c}34.5 \mathrm{~W} \text { for } \\
23 \text { hours }\end{array}$ & 22 \\
\hline
\end{tabular}

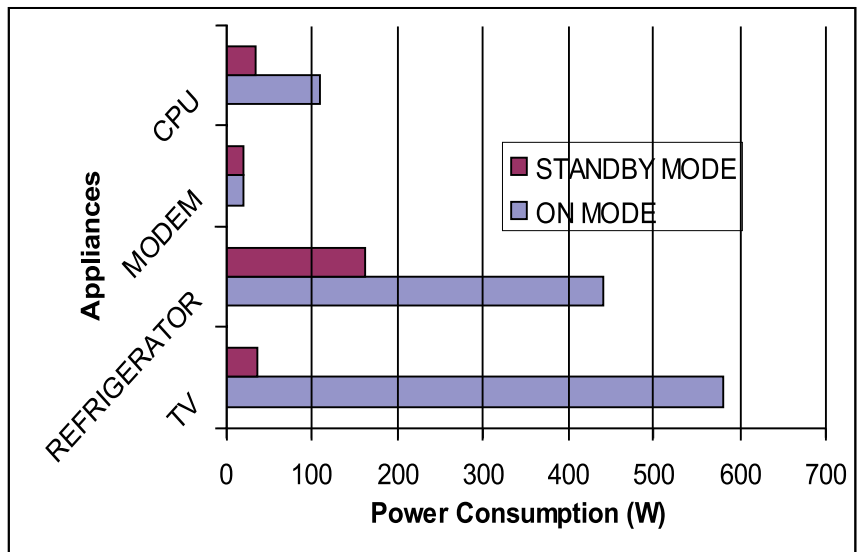

Figure 1. Typical Stanby power consumption for electrical appliances in Pondicherry

\section{Recommendations for immediate follow-up activities}

- Switch off the device when it is not in use.

- Insist manufacturers to build energy efficiency products.

- Promote programme that require measurement of stand by power consumption.

- Consistent approaches such as test procedures, standards and voluntary efforts could also benefit manufacturers by reducing costs and barriers to trade.

By observing the above recommendations energy can be saved for benefit of individual and of the nation.

\section{Conclusion}

As international approach to reduce standby power consumption can be reduced by an average of 75 per cent with cost effective design and technological improvements. Savings as high as 90 per cent can be achieved in many appliances without any reduction in services. International collaboration is essential to reduce standby power consumption, since many products are traded internationally. The problem is real, significant and should no longer be ignored. Economic activities are becoming increasingly equipment and appliances that consume power in standby modes. There are enough energy-efficient solutions already available in the market to make substantial reduction of standby power consumption a realistic objective. Reducing standby power at the international level is possible. Indeed it is already happening. Multinational companies have understood the need to improve the energy efficiency of the standby mode of the equipment they sell. This is encouraging, but government intervention can stimulate and reinforce such achievements. In the present work a case study was carried of standby power consumption for most used household power apparatus in the residential sector and the results infer that much of the energy can be saved by avoiding the standby power consumption and is equivalent to the production of electricity.

\section{References}

1. W. Mungwittikul and B. Mohanty, "Energy efficiency of office equipment in commercial buildings: The case of Thailand" Energy, Vol.22, No.7, pp.673-680,1997.

2. Brahman and Mohanty, "Perspectives for reduction of standby power consumption in electrical appliances", Guidebook on Promotion of Sustainable Energy Consumption. Nnited Nations, pp. 82-101, 2002.

3. Alan Meier, "Standby power - a quiet use of energy", CADDET Energy Efficiency newsletter, No. 4,1999.

4. International Energy Agency Report on, "Things that go blip in the night standby power and how to limit", 2001.

5. Economic and Social Commission for Asia and the Pacific, Guidebook on promotion of sustainable energy consumption. New York, 2002.

6. Takaji Matsunngaa, "Survey on actual standby power consumption of households", $3^{\text {rd }}$ International Workshop on standby power, Tokyo, 7-8, February 2001.

7. Marker and Harrington, "Standby power consumption in Australia: Results of Intrusive Monitoring", in Proc. $20013^{\text {rd }}$ International Workshop on Standby power.

8. Energy Efficiency Conservation Authority, "Energy use in New Zealand house", Report on the three analysis of the household energy end use project (HEEP), 1999.

9. A. Meier, K. Rosen and W. Huber, "Reducing leaking electricity to 1 watt", in Proc. 1998 ACEEE summer study on energy efficiency in buildings.

10. H. Nakagami, A. Tanaka, C. Murakoshi and B. Litt, "Standby electricity consumption in Japanese houses", in Proc. 1997 First International Conference on Energy Efficiency in Household Appliances.

11. J. Vowles, "Standby power in UK: Results of an extensive survey", in Proc. $20013^{\text {rd }}$ International Workshop on Standby Power.

12. Clement-Nyns, K., Pardon, I., Driesen, J. "Standby power consumption in Belgium", $9^{\text {th }}$ International Conference on Electrical Power Quality and Utilisation, 2007, EPQU 2007, Spain, Barcelona, 9-11 October 2007, pp.1-4.

13. P. Bertoldi, B. Aebischer, C. Edlington, C. Hershberg, B. Lebot, J. Lin, T. Marker, A. Meier, H. Nakagami, Y. Shibata, H. P. Siderius, C. Webber, "Standby power use: How big is the problem?", ACEEE 2002 Summer Study on Energy Efficiency in Buildings, August 18-23, Pacific Grove, California, USA, pp.1-20.

14. Commission of the European Communities, "Demand-side management, End-use metering campaign in 400 households of the European Community, Assessment of the potential electricity savings", Eureco Project, January 2002.

15. www.energilabel.ch

16. www.aceee.org

17. www.iea.org/standIby/index.html

18. www.energyefficient.com.au/standby/index.html

19. www.iea.org

20. www.unfcc.de

21. www.gealabel.org 